\title{
Problems and Solutions of Transport Logistics
}

\author{
Liudmyla Boldyrieva \\ Department of Management and \\ Logistics \\ Poltava National Technical Yuri \\ Kondratyuk \\ Poltava, Ukraine \\ Boldyrewaljuda@ukr.net
}

\author{
Halyna Zelinska \\ Ivano-Frankivsk National Technical \\ University of Oil And Gas \\ Ivano-Frankivsk, Ukraine \\ zelinska_haluna@i.ua
}

Anna Komelina

Department of Compliance

PJSC "Poltava-Bank"

Poltava, Ukraine

komelina.anna@gmail.com

\author{
Valentyna Krapkina \\ National University \\ of "Kyiv-Mohyla Academy" \\ Ukraine, Kyiv \\ valentina_31@i.ua
}

\begin{abstract}
Different approaches to the definition "transport logistics" have been generalized. It has been justified that transport is one of the main costs in the logistics system. The categorical apparatus of transport logistics has been presented, namely, the essence of such categories has been revealed: general function, purpose, task (creation of transport systems; joint planning of transport processes on different types of transport; ensuring technological unity of transport-warehouse process; coordination of transport and production processes; choice of vehicle type; choice of vehicle type; ensuring technological unity of the transport process; determining a rational delivery route; eliminating the purpose conflict, reducing transportation costs; and goals of increasing warehouse costs). The functions of transport logistics have beensuggested, in particular: system-forming, integrating, regulating, resultant, reproducing. The factors that led to the allocation of transportation into a separate functional area of logistics have been characterized. These factors include a large proportion of transportation costs in total logistics costs; impossibility of organization and existence of material flow without transportation. Transport-logistic systems have been classified by types: delivery, service, transport. It has been determined that transport logistics has been linked with other logistics systems by such elements as warehouses and inventory. Nine groups of global problems of transport logistics in Ukraine have been identified, including: financial, technical, technological, information, economic, international, customs, environmental, labor. The main directions of overcoming financial, technical, technological, information, economic, international, customs, environmental and labor problems have been formulated. It has been proposed to determine the capacity of the transport services market of a certain region as the sum of volumes transport services provided in a certain region by local transport enterprises; provided by transport companies in other regions; provided by own vehicles of nontransport enterprises, population, etc.; transport services, that are not provided by carriers due to lack of transport capacity.
\end{abstract}

Keywords-transport, transport logistics, management, material flows, cargo.

\section{INTRODUCTION}

Transport is one of the main objects of cost in the logistics system of the enterprise. Consequences of violations of the functioning of the transport system are damage to enterprises and even their bankruptcy.
The issue of transport logistics development has been widely researched by scientists. For example, A. Dubois, K. Hulthén, V. Sundquist [1] consider the problems of the transport logistics organization in construction impact on the efficiency of the economic system.

It has been acknowledged that logistics is a driving force that shapes the integration of the transport chain. This paper argues that while the liner shipping industry exhibits increased horizontal integration, its vertical integration remains limited. A clear distinction is drawn between freight logistics, container logistics and vessel logistics. Freight logistics is defined as part of the supply chain process, the focus of which is the goods being transported. The purpose of container logistics is to optimize the movements of the containers themselves, an operation that is directly related to vessel logistics which is concerned with maximizing vessel utilization. The paper demonstrates that shipping lines have to find the correct balance between these three types of logistics [2]. Their interest in vertical integration is primarily because the management of container logistics provides direct support to vessel logistics. Their involvement in freight logistics remains unclear and uncertain.

Logistics is a major component of modern production and distribution systems and a key contributor to macroeconomic development. Comprehensive logistics costs represent approximately $10 \%$ of GNP in developed countries, and even more in less-advanced ones. Beyond its costs, logistics efficiency or inefficiency affects the whole production and exchange process. In fact, three main families of definitions of logistics coexist. The first consists of a range of physical operations, a changing location of goods in space and time, and comprises transport, handling, packaging, sorting, and warehousing. Logistics is also the name of a branch of management sciences, considering the firm and the relationships between firms as a system of flows (flows of products and flows of information), allowing a comprehensive monitoring and steering of "supply chains". Finally, logistics is an emerging industry, gathering several traditional professions into a single integrated one (i.e. logistics service provision), including its real estate and integrating post offices henceforth competing on an open courier and freight market. Freight transport roughly represents the half of total logistics costs. Biggest logistics third-party providers (3PL) originate from the transport industry. Still, a substantial share of logistics activities continues to be carried out inside agricultural, industrial or commercial firms (in-house, or own-account, logistics). All 
these three definitions of logistics make sense and one does not have to choose between them, but to combine them [3].

M. Hesse and J-P. Rodrigue consider the issues of movement and distribution of goods in geography terms. according to scientists, the flow of goods is influenced by information flows, structural changes in production, financial factors [4]. Z. Bokor consider a ways to improve the methods of costing in transport logistics [5].

V. Lukinsky and V. Dobromirov also review methods of evaluating transportation and logistics operations in supply chains. Also, scientists pay attention to the classical model of Harris-Wilson [6].

Supply chains, logistics and freight have been facing increasingly complex challenges posed by transitions in economic structures, urbanization, city design and transport systems, as well as by the externalities associated with logistics activities in urban areas. This has driven a great deal of research recently. Yet, there are no sufficient contributions clarifying the current state of thought in this field. First, to provide a framework with geographical and functional elements of urban logistics. Second, to identify the scope of the literature, vested into a typology. And third, to define the terms that may embrace the various analytical interests of the urban logistics field, namely city logistics, urban goods distribution and last mile logistics [7].

Analysis of the issue of «transport logistics» suggests the existence of different points of view among scholars on the essence of the concept itself. The term «transport logistics» shall be construed as:

the whole science, which is related to the search for opportunities to increase the efficiency of the movement of material flows, the purpose of which is to ensure the transport of high-quality;

functional area of logistics that optimizes logistics operations on the way of material flow from supplier to final consumer, carried out with the use of vehicles;

a system for organizing the delivery of goods by road, from one point to another along the optimal route, which allows maximum reduction of terms and financial costs of delivery;

the field of activity in the management of cargo transportation, that is, the change in the location of material assets using vehicles;

a comprehensive approach to the development of all logistic elements, including transport, on the basis of which the formation of innovative transport systems for the collection and distribution of material products.

Transport is not just one of the elements of logistics, but the main means by which logistics, regardless of its scale, is expressed in life.

The general function of transport logistics is the management of material flows throughout the length of the logistics channels, from the source of generation to the destination.

The purpose of transport logistics is to promote material flows to the consumer strictly according to the schedule at a set time, with minimal costs for all participants in the movement of goods. And the very implementation of the concept of transport logistics helps to find rational solutions to complex socioeconomic problems in real time and in the future.

The purpose of transport logistics is determined by the goal of the logistics company: the required cargo must be delivered at the right time to the right place in the right amount in the right quality and with minimal cost.

The functions of transport logistics applied in practice include:

the system-forming function is manifested when the resource management process is ensured; the formation of a commodity management system (the formation of economic ties); organization of product movement through warehouses; formation and regulation of product stocks; development and organization of logistics centers;

integrating - while ensuring synchronization of sales processes; storage and delivery of products with their orientation on the market of means of production and provision of intermediary services to consumers; ensuring coordination of interests of logistic intermediaries in the logistics system; ensuring the functioning of material flows at all stages of reproduction of the final product; a combination of the processes of «supply - production processing - marketing» in one logistics chain;

regulatory - the management of material flows is aimed at saving all types of resources; Reducing the cost of living and pre-owned parks at the junction of different organizational and economic levels and industries;

the resulting function is directed at the supply of certain products in the required quantity, the given quality, at the specified time and place, with minimal expenses;

reproducing - a constant exchange of goods in the form of continuous material flows, which are provided by transport.

Tasks of transport logistics:

creation of transport systems, in particular the creation of transport corridors and transport chains;

joint planning of transport processes in different types of transport;

ensuring the technological unity of the transport and warehouse process;

coordination of transport and production processes;

choice of vehicle type;

ensuring the technological unity of the transport process;

definition of rational delivery route;

eliminating conflict methods, reducing transportation costs and improving warehouse costs.

The separation of transportation into a separate functional area of logistics is conditioned by the following factors:

1) a large share of transport costs in the total logistics costs;

2) impossibility of organization and existence of material flow without transportation.

We propose to determine capacity of transport services market in a certain region $\left(\mathrm{CM}_{\mathrm{ts}}\right)$ by the formula (1):

$$
\mathrm{CM}_{\mathrm{ts}}=\mathrm{V}_{\mathrm{ts} 1}+\mathrm{V}_{\mathrm{ts} 2}+\mathrm{V}_{\mathrm{ts} 3}+\mathrm{V}_{\mathrm{ts} 4} \text {, }
$$

$\mathrm{CM}_{\mathrm{ts}}$ - capacity of transport services market in a certain region;

$\mathrm{V}_{\mathrm{ts} 1}$ - volume of transport services that provided in a particular region by local transport companies;

$\mathrm{V}_{\mathrm{ts} 2}$ - volumes of transport services that provided in a certain region by transport enterprises in other regions;

$\mathrm{V}_{\mathrm{ts} 3}$ - volumes of transport services that provided by own vehicles of non-transport enterprises, population, etc.;

$\mathrm{V}_{\mathrm{ts} 4}$ - volumes of transport services that were not provided by carriers due to lack of transport capacity. 
There are the following signs of classification of the transport component of logistics systems:

according to the type of delivery: direct; with processing at transport terminals; with processing and storage in distribution centers;

by type of service: from the supplier or distribution center to a consumer warehouse or distribution center; from the supplier or distribution center of the immediate consumer; from the supplier's production to consumer production without warehouse storage and processing;

by types of transport: direct; mixed up.

Transport logistics is characterized by key elements: transport links with suppliers and consumers, freight shipped. The process of transportation begins from the warehouse of finished products, ends with the receipt of goods into warehouses of consumers or intermediaries.

For transport logistics, such elements as warehouses, stocks of products that connect it with other logistic systems are characteristic. As an integral part of the transport logistics, the goods become goods that are transported to transport for carriage from the moment they are received to the carriage and until the transfer to the recipient.

The volume of transportation, directions and nomenclature of transportations is considered by transport logistics. Defines the subjects of the commodity market, which belong to the subsystems of transportation logistics, which are managed and managed. Variants of transportation, which depend on the types of used vehicles (rail, road, water, air, pipeline), mixed transport, several types of transport, are important for transportation logistics.

Thus, the development of logistics has had a significant impact on transport policy and structural changes in the nature of the enterprises of this industry, which in the late 70 ies of the XX century turned into a kind of narrow place in the economy of industrialized countries.

Transport plays the role of a connecting link in the logistic chain production in the conditions of inter-industry, and inter-sectoral integration. At the same time, transport provides transportation services on the market, for which they also make a profit. Actuality of problems of management and optimization of transport work is confirmed by the fact that the share of transport costs is 40$50 \%$ of the total amount of logistics costs.

In modern logistics of transport there are many problems. The study of these problems was dealt with and addressed by various authors of books, articles on logistics and transport logistics, and conferences on their study and decision.

Generalization of the problems of transport logistics in Ukraine is of great importance. There are 9 groups of global problems of transport logistics in Ukraine under the conditions of European integration and formulate the main directions of overcoming these problems [8] (Figure 1, Table I-II).

\begin{tabular}{|c|c|c|c|c|}
\hline Financial & Technical & Technological & \multicolumn{2}{|r|}{ Information } \\
\hline 소 & 4 & 소 & 소 & \\
\hline \multicolumn{4}{|c|}{$\begin{array}{l}\text { Global problems of transport logistics in Ukraine } \\
\text { in conditions of European integration }\end{array}$} & Labor \\
\hline $\bar{t}$ & 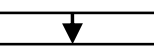 & 7 & & \\
\hline Economi & International & Customs & Env & ironmental \\
\hline
\end{tabular}

Fig. 1. Groups of global problems of transport logistics in Ukraine in conditions of European integration
TABLE I. GLOBAL PROBLEMS OF TRANSPORT LOGISTICS IN UKRAINE IN CONDITIONS OF EUROPEAN INTEGRATION

\begin{tabular}{|c|c|}
\hline Group name & List of problems \\
\hline $\begin{array}{l}\text { Financial } \\
\text { problems }\end{array}$ & $\begin{array}{l}\text { 1) lack of investments and lack of own funds for } \\
\text { reconstruction of roads, renewal of rolling stock, } \\
\text { signaling system, communication, improvement of } \\
\text { service quality; }\end{array}$ \\
\hline $\begin{array}{l}\text { Technical } \\
\text { problems }\end{array}$ & $\begin{array}{l}\text { 1) non-loading of rolling stock, in particular } \\
\text { insufficient use of load-carrying capacity or useful } \\
\text { internal volume of a vehicle's body; } \\
\text { 2) the quality of transport services; } \\
\text { 3) the complexity of transportation by several types } \\
\text { of transport; } \\
\text { 4) outdated material and technical base, low level of } \\
\text { mechanization of transshipment, considerable } \\
\text { physical and moral depreciation; } \\
\text { 5) operational incompatibility of transport networks, } \\
\text { in particular their exhaustive bandwidth; } \\
\text { 6) lagging speed (on European railways } 200-250 \mathrm{~km} \\
\text { / h, Ukrainian - } 160 \mathrm{~km} / \mathrm{h} \text { ); }\end{array}$ \\
\hline $\begin{array}{c}\text { Technological } \\
\text { problems }\end{array}$ & $\begin{array}{l}\text { 1) the use of vehicles, which have already several } \\
\text { times worked out their technical resources and carry } \\
\text { out significantly higher emissions of harmful } \\
\text { substances; } \\
\text { 2) low quality of internal roads, which increase fuel } \\
\text { consumption due to poor quality roads; } \\
\text { 3) out-of-date technologies that do not meet current } \\
\text { standards; } \\
\text { 4) the backwardness of the transport infrastructure; } \\
\text { low technical and technological level and level of } \\
\text { organization of transportation management; }\end{array}$ \\
\hline $\begin{array}{l}\text { Information } \\
\text { problems }\end{array}$ & $\begin{array}{l}\text { 1) complexity in the construction of optimal routes of } \\
\text { traffic (transportation); } \\
\text { 2) insufficient information support of carriers; } \\
\text { 3) lack of information about programs that allow } \\
\text { automation of the transportation process; }\end{array}$ \\
\hline $\begin{array}{l}\text { Economic } \\
\text { problems }\end{array}$ & $\begin{array}{l}\text { 1) a constant increase in the cost of all types of } \\
\text { transportation, including oil prices, fuel, lubricants, } \\
\text { light and dark petroleum products, energy resources; } \\
\text { 2) different conditions for payment for the use of } \\
\text { infrastructure by carriers, including Ukrzaliznytsya; }\end{array}$ \\
\hline $\begin{array}{c}\text { International } \\
\text { problems }\end{array}$ & $\begin{array}{l}\text { 1) not predictable risks associated with changing } \\
\text { climatic conditions; } \\
\text { 2) the lack of a single register of vehicles (in } \\
\text { practice, it leads to the fact that the same car can be } \\
\text { simultaneously booked on different routes by } \\
\text { different dispatchers); } \\
\text { 3) failures of submission of motor vehicles in agreed } \\
\text { dates for loading; }\end{array}$ \\
\hline $\begin{array}{c}\text { Environmental } \\
\text { problems }\end{array}$ & $\begin{array}{l}\text { 1) pollution of the environment; } \\
\text { 2) absence of additional charges for environmental } \\
\text { pollution and noise; }\end{array}$ \\
\hline $\begin{array}{c}\text { Labor } \\
\text { problems }\end{array}$ & $\begin{array}{l}\text { 1) insufficient number of skilled logistics personnel, } \\
\text { including logistic operators; } \\
\text { 2) insufficiently developed cooperation between } \\
\text { commodity producers, which complicates the } \\
\text { processes of integration and cooperation; } \\
\text { 3) decrease of competitiveness of Ukrainian carriers. }\end{array}$ \\
\hline
\end{tabular}

Transport activities in market relations should develop in the following directions: in-depth study of demand using transport balances of regions; improving the quality and reliability of customer service; improvement of the whole complex of loading and unloading and storage works; provision of information and forwarding services; increase of contractual relations; development of service services; the creation of enterprises that would be part of different associations, joint-stock companies partnerships, leasing companies, etc.; creation of intermediary firms for the 
supply of rolling stock, logistics, marketing, advertising; distribution of container usage.

\section{TABLE II. DIRECTIONS TO OVERCOMING PROBLEMS}

\begin{tabular}{|c|c|}
\hline Group name & Directions to overcoming problems \\
\hline $\begin{array}{l}\text { Financial } \\
\text { problems }\end{array}$ & $\begin{array}{l}\text { 1) development of programs for the purchase of fixed } \\
\text { assets and rolling stock in leasing; } \\
\text { 2) development of targeted financing and investment } \\
\text { programs, modernization, reconstruction and } \\
\text { updating of rolling stock; }\end{array}$ \\
\hline $\begin{array}{l}\text { Technical } \\
\text { problems }\end{array}$ & $\begin{array}{l}\text { 1) an effective renovation of the car park, capable of } \\
\text { providing sufficient transport services of adequate } \\
\text { quality and satisfaction; } \\
\text { 2) optimization of the transportation process itself by } \\
\text { collecting consolidated cargo from several senders, } \\
\text { compiling optimal routes of routing, connecting a } \\
\text { more efficient mode of transport on a certain route; } \\
\text { 3) the introduction of technical policy at motor } \\
\text { transport companies with the coordination of } \\
\text { maintenance procedures for types of rolling stock and } \\
\text { the introduction of a modern system of spare parts } \\
\text { supply, based on the control and analysis of the } \\
\text { causes of failure of parts, units and nodes; }\end{array}$ \\
\hline $\begin{array}{c}\text { Technological } \\
\text { problems }\end{array}$ & $\begin{array}{l}\text { 1) search for new products and technologies; } \\
\text { 2) integration into the pan-European transport system; } \\
\text { 3) increasing the level of transport security; } \\
\text { 4) implementation of SAP software; } \\
\text { 5) change of approaches to management of all } \\
\text { economic processes; } \\
\text { 6) to create a network of automated traffic } \\
\text { management, with the reduction of reloading } \\
\text { operations; }\end{array}$ \\
\hline $\begin{array}{l}\text { Information } \\
\text { problems }\end{array}$ & $\begin{array}{l}\text { 1) the application of the latest computer technologies } \\
\text { in transport and logistics for the processing of large } \\
\text { amounts of information, the exchange of data in real } \\
\text { time with minimal cost; }\end{array}$ \\
\hline $\begin{array}{l}\text { Economic } \\
\text { problems }\end{array}$ & $\begin{array}{l}\text { 1) the return to the methodology for calculating the } \\
\text { cost of transportation and taking into account not the } \\
\text { market price per } 1 \mathrm{~km} \text {, but the individual profitability } \\
\text { of each transportation; } \\
\text { 2) comprehensive accounting of logistics costs; } \\
\text { 3) refusal of cross-financing of passenger } \\
\text { transportation; }\end{array}$ \\
\hline $\begin{array}{c}\text { International } \\
\text { problems }\end{array}$ & $\begin{array}{l}\text { 1) Adaptation of the national legal framework to } \\
\text { international conventions, agreements, European } \\
\text { acguis communautaire; } \\
\text { 2) attraction of additional volumes of transit traffic } \\
\text { through the territory of Ukraine and branching of the } \\
\text { MTK network due to new directions of movement; } \\
\text { 3) cooperation with the EU countries in the } \\
\text { development of Trans-European Networks (TEN-T), } \\
\text { transnational axes; } \\
\text { 4) creation of a common aviation space between } \\
\text { Ukraine and the EU; }\end{array}$ \\
\hline $\begin{array}{l}\text { Environmenta } \\
1 \text { problems }\end{array}$ & $\begin{array}{l}\text { 1) reduction of atmospheric air and soil pollution, } \\
\text { protection of surface and groundwater from pollution; } \\
\text { 2) reduction of transport noise and vibration; } \\
\text { 3) protection of flora and fauna from the harmful } \\
\text { effects of transport; }\end{array}$ \\
\hline $\begin{array}{c}\text { Labor } \\
\text { problems }\end{array}$ & $\begin{array}{l}\text { 1) improvement of transport legislation; } \\
\text { 2) «erosion» of the borders with EU countries, which } \\
\text { will ensure the attractiveness of the transportation } \\
\text { sector; } \\
\text { 3) increase of transport operators, increase internal } \\
\text { competition and promote tariff crash; } \\
\text { 4) increase of wages of drivers. }\end{array}$ \\
\hline
\end{tabular}

Thus, the general strategic direction is to improve the transport complex of Ukraine in the conditions of European integration, according to which the state of transport communications of Ukraine should meet the needs of European integration. That is why it is necessary:

complexly at the state level to put problems associated with the development of the transport network, identify tasks and ways to solve them, find appropriate support: financial, logistical, resource, organizational, legal;

to develop and implement the State Program for the development of the transport complex in Ukraine (the complexity of managing such a program is complicated by an increase in privatization processes in the transport system);

to develop a number of motives, levers, methods and methods for the development of the transport system in the country (the development of the transport network is a level of technological progress and civilization of the country);

a steady tendency towards Ukraine's recognition of the international community as a European state, with which it is desirable to have stable and broad-based business relations and which in the long run will have a serious impact on key issues of European politics;

the existence of an approved concept for the creation and functioning in Ukraine of a national network of international transport corridors.

\section{REFERENCES}

[1] A. Dubois, K. Hulthén, V. Sundquist, (2019) «Organising logistics and transport activities in construction», The International Journal of Logistics Management, Vol. 30 Issue: 2, pp.620640, https://doi.org/10.1108/IJLM-12-2017-0325.

[2] A. Frémont (2009) «Shipping Lines and Logistics» Transport Reviews, Vol. 29, Issue: 4, pp. 537-554, https://doi.org/10.1080/01441640802677607.

[3] M. Savy (2016) Logistics as a political issue, Transport Reviews, 36:4, 413-417, DOI: 10.1080/01441647.2016.1182793.

[4] M. Hesse and J-P. Rodrigue (2004) «The transport geography of logistics and freight distribution» Journal of Transport Geography Vol. 12, Issue 3, September 2004, pp. 171-184 https://doi.org/10.1016/j.jtrangeo.2003.12.004.

[5] Z. Bokor (2010) «Cost drivers in transport and logistics», Periodica Polytechnica Transportation Engineering, 38(1), pp. 13-17. doi: https://doi.org/10.3311/pp.tr.2010-1.03.

[6] V. Lukinskiy and V. Dobromirov (2016) Methods of Evaluating Transportation and Logistics Operations in Supply Chains Volume/Issue: Vol. 17: Issue 1 pp: 55-59. doi: https://doi.org/10/1515/ ttj-2016-0006.

[7] I. Cardenas, Ya. Borbon-Galvez, T. Verlinden (2017) City logistics, urban goods distribution and last mile delivery and collection First Published November 2, 2017 Research Article https: //doi.org/10.1177/1783591717736505.

[8] V. Grihcko and L. Boldyrieva (2016) «Management of Transport Logistics under the Conditions of European integration processes». ECONOMICS AND REGION, Vol. 1(56). pp. 31-37.

[9] H. Zelinska, L. Boldyrieva and I. Amelina (2018) Logistic quality management of transport process in construction / International Journal of Engineering \& Technology, 7 (3.2). pp. 32-35. Website: www.sciencepubco.com/ index.php/IJET doi: 10.14419/ijet.v7i3.2.14371.

[10] E. Barry Yui-yip Lau (2016) Market potential for transport airships in service to Hong Kong. Volume 3, Issue 1; https://doi.org/10.1504/IJAM.2016.078665/. 